\title{
A Developed Systematic Literature Review Procedure with Application in the Field of Digital Transformation
}

\author{
HAMDAN ALMASRI ${ }^{1}$, NORHAYATI ZAKUAN ${ }^{2}$, MOHAMED SALEH AMER ${ }^{3}$, M. RAFEE MAJID ${ }^{4}$ \\ ${ }^{1}$ Faculty of Finance \& Management, UNIVERSITY OF PALESTINE, PALESTINE. E-mail: h1978@graduate.utm.my \\ ${ }^{1,2}$ Azman Hashim International Business School, UNIVERSITI TEKNOLOGI MALAYSIA (UTM), MALAYSIA \\ ${ }^{3,4}$ Department of Urban and Regional Planning, Faculty of Built Environment and Surveying, UNIVERSITI \\ TEKNOLOGI MALAYSIA (UTM), MALAYSIA
}

\begin{abstract}
This paper aims to make a methodological contribution to the systematic review method for business and social science research and to implement the proposed procedure in the field of digital transformation. In this article, we reviewed the systematic reviews found in the literature on bibliometric analysis and the Preferred Reporting Items for Systematic Reviews and Meta-Analysis (PRISMA) guidelines in several databases, namely Scopus, Web of Science, SpringerLink Journal, and Google Scholar, in addition to systematic literature searches on digital transformation in the fields of business and social sciences available in the Scopus database. We also combined the bibliometric analysis, PRISMA model, and software analysis to establish filters that support authors in identifying relevant literature to facilitate and improve the extraction, visualisation, and analysis of data. The developed method consisted of four stages: research design, data collection, data analysis, and visualisation. The proposed systematic review process and its application presented in this paper provide an effective process for systematic literature review in the field of business and social science. A notable contribution of this study is the inclusion of the developed PRISMA guidelines in the bibliometric standard workflow and the expansion in the use and application of analysis software.
\end{abstract}

Keywords: Digital Transformation, Systematic Literature Review, Biometrics Analysis, PRISMA guidelines

JEL Classification: M10

Recibido: 7 de Febrero de 2021

Aceptado: 2 de Noviembre de 2021 


\section{Introduction}

A systematic literature review is recognised as a valid and important approach to explore the existing knowledge base of research in various fields (Corallo et al. 2019, 2020; Creswell and Creswell 2017; Santos-Neto and Costa 2019; Tranfield, Denyer, and Smart 2003). The systematic literature search is also an important tool to summarise available information, sort empirical evidence that meets defined eligibility criteria, and answer specific research questions accurately and reliably. In comparison to other literature research methods, a systematic review focuses on explicit, systematic methods that improve the reliability of the results and reduce any possible prejudice (Satalkina and Steiner 2020). While there are several suggested procedures to conduct a systematic literature review, recent systematic literature reviews have begun to incorporate software programs as supporting tools to manage and synthesise the reviewed literature (Alsolami and Embi 2018).

Therefore, given the above discussion, this study aims to provide an overview of the available systematic review articles found in the literature on bibliometric analysis and the PRISMA model with VOSviewer software. Secondly, this study aims to contribute to the systematic review method in business and social science research, especially in the field of digital transformation through the combination of bibliometric analysis, PRISMA model, and analysis software programs.

In achieving this aim, this article seeks answers to the following research questions: What are the systematic reviews found in the literature on bibliometric analysis and PRISMA guidelines with VOSviewer software in Scopus, the Web of Science, the SpringerLink Journal, and the Google Scholar databases? What are the available systematic review articles in the Scopus database on digital transformation in the business and social sciences fields? The remainder of this paper will report on implementing the proposed systematic literature research procedures to review the area of digital transformation in business and social sciences.

\section{Literature review}

This This section provides an overview of systematic reviews of the literature on bibliometric analysis and the PRISMA guidelines in Scopus, Web of Science, SpringerLink Journal, and Google Scholar databases and systematic literature reviews on digital transformation in business and social sciences fields that are accessible in the Scopus database.

The searches of the Scopus, Web of Science, SpringerLink Journal, and Google Scholar databases highlighted several systematic literature reviews applying bibliometric analysis and the PRISMA guidelines as a research method. The search was performed on 5th July 2020 with the research strategy adopted shown in Table 1 below.

Table 1: Search strategy in Scopus, Web of Science, SpringerLink Journal, and Google Scholar databases.

\begin{tabular}{|c|c|c|}
\hline Database & Details of the Search & Result of search \\
\hline Scopus & $\begin{array}{l}\text { (TITLE-ABS-KEY ( "systematic literature review" ) OR TITLE- } \\
\text { ABS-KEY ( "SLR" ) OR TITLE-ABS-KEY ( "systematic mapping" ) } \\
\text { OR TITLE-ABS-KEY ( "structure literature review" ) AND ALL ( } \\
\text { "bibliometric" ) AND ALL ( "Prisma" ) AND ALL ( "VOSviewer" ) ) }\end{array}$ & 18 Articles \\
\hline $\begin{array}{l}\text { Web of Science } \\
\text { All Databases }\end{array}$ & $\begin{array}{l}\text { TOPIC: ("systematic literature review" OR "SLR" OR "structure } \\
\text { literature review" OR "systematic mapping") AND ALL FIELDS: } \\
\text { ("bibliometric") AND ALL FIELDS: ("Prisma") } \\
\text { Timespan: All years. Indexes: SCI-EXPANDED, SSCI, A\&HCI, } \\
\text { CPCI-S, CPCI-SSH, BKCI-S, BKCI-SSH, ESCI. }\end{array}$ & 8 Articles \\
\hline SpringerLink Journal & $\begin{array}{c}\text { "'systematic literature review" OR "SLR" OR "systematic mapping" } \\
\text { OR "structure literature review" AND "bibliometric" AND "prisma" } \\
\text { AND "VOSviewer" ' }\end{array}$ & 3 Articles \\
\hline Google Scholar & "bibliometric" "prisma" "VOSviewer" " nvivo" & 7 Articles \\
\hline
\end{tabular}

A total of s eighteen articles were discovered in the Scopus database, three articles in the Springer database, eight articles in the Web of Science database, and six articles in Google Scholar. After excluding duplicate articles and non-English publications, 32 articles ready to review. Table 2 shows the research area and software used in these articles. 
Table 2: Search result in the databases Scopus, Web of Science, SpringerLink Journal, and Google Scholar.

\begin{tabular}{|c|c|c|c|c|c|c|}
\hline \multirow[b]{2}{*}{ Article } & \multicolumn{4}{|c|}{ Database } & \multirow[b]{2}{*}{ Area of Research } & \multirow{2}{*}{$\begin{array}{l}\text { Analysis } \\
\text { Software }\end{array}$} \\
\hline & Scopus & $\begin{array}{l}\text { Web of } \\
\text { Science }\end{array}$ & $\begin{array}{l}\text { Google } \\
\text { Scholar }\end{array}$ & Springer & & \\
\hline $\begin{array}{l}\text { A systematic literature review } \\
\text { to explore traceability and } \\
\text { lifecycle relationship } \\
\text { (Corallo et al. 2020) }\end{array}$ & $\checkmark$ & l & l & l & $\begin{array}{l}\text { (Business, } \\
\text { Management and } \\
\text { Accounting) } \\
\text { (Decision } \\
\text { Sciences) } \\
\text { (Engineering) }\end{array}$ & $\begin{array}{c}\text { VOSviewer } \\
\text { software }\end{array}$ \\
\hline $\begin{array}{l}\text { Business Model Innovation } \\
\text { (BMI) Process: A Systematic } \\
\text { Literature Review with } \\
\text { Bibliometric Analysis } \\
\text { (Schaller and Vatananan- } \\
\text { Thesenvitz 2019) }\end{array}$ & $\checkmark$ & l & l & / & $\begin{array}{c}\text { (Business, } \\
\text { Management and } \\
\text { Accounting) } \\
\text { (Computer } \\
\text { Science) } \\
\text { (Decision } \\
\text { Sciences) } \\
\text { (Engineering) }\end{array}$ & $\begin{array}{c}\text { VOSviewer } \\
\text { software }\end{array}$ \\
\hline $\begin{array}{c}\text { Climate Change Mitigation: } \\
\text { Application of Management } \\
\text { Production Philosophies for } \\
\text { Energy Saving in Industrial } \\
\text { Processes } \\
\text { (Niñerola, Ferrer-Rullan, and } \\
\text { Vidal-Suñé 2020) }\end{array}$ & $\checkmark$ & l & l & l & $\begin{array}{l}\text { (Energy) } \\
\text { (Environmental } \\
\text { Science) (Social } \\
\text { Sciences) }\end{array}$ & $\begin{array}{c}\text { VOSviewer } \\
\text { software }\end{array}$ \\
\hline $\begin{array}{l}\text { Decision support system in } \\
\text { supply chain: A systematic } \\
\text { literature review } \\
\text { (Teniwut and Hasyim 2020) }\end{array}$ & $\checkmark$ & l & l & l & $\begin{array}{l}\text { (Business, } \\
\text { Management and } \\
\text { Accounting) } \\
\text { (Decision } \\
\text { Sciences) }\end{array}$ & $\begin{array}{l}\text { VOSviewer } \\
\text { software } \\
\text { Microsoft } \\
\text { Excel }\end{array}$ \\
\hline $\begin{array}{l}\text { Enterprise maturity models: a } \\
\text { systematic literature review } \\
\text { (Santos-Neto and Costa } \\
\text { 2019) }\end{array}$ & $\checkmark$ & / & l & / & $\begin{array}{l}\text { (Computer } \\
\text { Science) } \\
\text { (Decision } \\
\text { Sciences) }\end{array}$ & $\begin{array}{c}\text { VOSviewer } \\
\text { software }\end{array}$ \\
\hline $\begin{array}{l}\text { Human Factor in Food Label } \\
\text { Design to Support Consumer } \\
\text { Healthcare and Safety: A } \\
\text { Systematic Literature Review } \\
\text { (Corallo et al. 2019) }\end{array}$ & $\checkmark$ & l & l & l & $\begin{array}{c}\text { (Energy) } \\
\text { (Environmental } \\
\text { Science) (Social } \\
\text { Sciences) }\end{array}$ & $\begin{array}{c}\text { VOSviewer } \\
\text { software }\end{array}$ \\
\hline $\begin{array}{l}\text { Life cycle modeling for } \\
\text { environmental management: a } \\
\text { review of trends and linkages } \\
\text { (Sharma and Gupta 2020) }\end{array}$ & $\checkmark$ & l & l & l & $\begin{array}{c}\text { (Environmental } \\
\text { Science) }\end{array}$ & $\begin{array}{c}\text { VOSviewer } \\
\text { software }\end{array}$ \\
\hline $\begin{array}{l}\text { Reverse logistics for the end- } \\
\text { of-life and end-of-use } \\
\text { products in the } \\
\text { pharmaceutical industry: a } \\
\text { systematic literature review } \\
\text { (de Campos et al. 2017) }\end{array}$ & $\checkmark$ & I & l & l & $\begin{array}{l}\text { (Business, } \\
\text { Management and } \\
\text { Accounting) }\end{array}$ & $\begin{array}{c}\text { VOSviewer } \\
\text { software }\end{array}$ \\
\hline $\begin{array}{l}\text { Save Lives: A Review of } \\
\text { Ambulance Technologies in } \\
\text { Pre-Hospital Emergency } \\
\text { Medical Services } \\
\text { (Pulsiri et al. 2019) }\end{array}$ & $\checkmark$ & l & l & l & $\begin{array}{c}\text { (Business, } \\
\text { Management and } \\
\text { Accounting) } \\
\text { (Computer } \\
\text { Science) } \\
\text { (Decision } \\
\text { Sciences) } \\
\text { (Engineering) }\end{array}$ & $\begin{array}{c}\text { VOSviewer } \\
\text { software }\end{array}$ \\
\hline
\end{tabular}




\begin{tabular}{|c|c|c|c|c|c|c|}
\hline $\begin{array}{l}\text { Simulation-based optimization } \\
\text { methods applied in hospital } \\
\text { emergency departments: A } \\
\text { systematic review } \\
\text { (Yousefi, Yousefi, and } \\
\text { Fogliatto 2020) }\end{array}$ & $\checkmark$ & 1 & I & 1 & $\begin{array}{c}\text { (Computer } \\
\text { Science) } \\
\text { (Mathematics) }\end{array}$ & $\begin{array}{l}\text { VOSviewer } \\
\text { software }\end{array}$ \\
\hline $\begin{array}{c}\text { Sustainability Outcomes of } \\
\text { Green Processes in Relation } \\
\text { to Industry } 4.0 \text { in } \\
\text { Manufacturing: Systematic } \\
\text { Review } \\
\text { (Vrchota et al. 2020) }\end{array}$ & $\checkmark$ & 1 & 1 & 1 & $\begin{array}{l}\text { (Energy) } \\
\text { (Environmental } \\
\text { Science) (Social } \\
\text { Sciences) }\end{array}$ & $\begin{array}{l}\text { VOSviewer } \\
\text { software } \\
\text { Endnote } \\
\text { software }\end{array}$ \\
\hline $\begin{array}{l}\text { Sustainable construction } \\
\text { management: A systematic } \\
\text { review of the literature with } \\
\text { meta-analysis } \\
\text { (Araújo et al. 2020) }\end{array}$ & $\checkmark$ & 1 & I & 1 & $\begin{array}{c}\text { (Business, } \\
\text { Management and } \\
\text { Accounting) } \\
\text { (Energy) } \\
\text { (Engineering) } \\
\text { (Environmental } \\
\text { Science) }\end{array}$ & $\begin{array}{l}\text { VOSviewer } \\
\text { software }\end{array}$ \\
\hline $\begin{array}{l}\text { Systematic literature review } \\
\text { on the spread of health- } \\
\text { related misinformation on } \\
\text { social media } \\
\text { (Wang et al. 2019) }\end{array}$ & $\checkmark$ & 1 & I & 1 & $\begin{array}{c}\text { (Arts and } \\
\text { Humanities) (Social } \\
\text { Sciences) }\end{array}$ & $\begin{array}{l}\text { VOSviewer } \\
\text { software }\end{array}$ \\
\hline $\begin{array}{c}\text { The Potential of Open Space } \\
\text { for Enhancing Urban Seismic } \\
\text { Resilience: A literature } \\
\text { Review } \\
\text { (Koren and Rus 2019) }\end{array}$ & $\checkmark$ & I & I & 1 & $\begin{array}{l}\text { (Energy) } \\
\text { (Environmental } \\
\text { Science) (Social } \\
\text { Sciences) }\end{array}$ & $\begin{array}{l}\text { VOSviewer } \\
\text { software }\end{array}$ \\
\hline $\begin{array}{c}\text { The reefer container market } \\
\text { and academic research: a } \\
\text { review study } \\
\text { (Castelein, Geerlings, and } \\
\text { Van Duin 2020) }\end{array}$ & $\checkmark$ & I & 1 & 1 & $\begin{array}{l}\text { (Business, } \\
\text { Management and } \\
\text { Accounting) } \\
\text { (Energy) } \\
\text { (Engineering) } \\
\text { (Environmental } \\
\text { Science) }\end{array}$ & $\begin{array}{l}\text { VOSviewer } \\
\text { software } \\
\text { Covidence } \\
\text { systematic } \\
\text { review } \\
\text { software } \\
\text { Gephi } \\
\text { software }\end{array}$ \\
\hline $\begin{array}{c}\text { Towards Sustainable } \\
\text { Entrepreneurship Holistic } \\
\text { Construct } \\
\text { (Konys 2019) }\end{array}$ & $\checkmark$ & I & 1 & 1 & $\begin{array}{l}\text { (Energy) } \\
\text { (Environmental } \\
\text { Science) (Social } \\
\text { Sciences) }\end{array}$ & $\begin{array}{l}\text { VOSviewer } \\
\text { software }\end{array}$ \\
\hline $\begin{array}{c}\text { Trends in Educational } \\
\text { Research about e-Learning: A } \\
\text { Systematic Literature Review } \\
(2009--2018) \\
\text { (Valverde-Berrocoso et al. } \\
\text { 2020) }\end{array}$ & $\checkmark$ & I & I & 1 & $\begin{array}{l}\text { (Energy) } \\
\text { (Environmental } \\
\text { Science) (Social } \\
\text { Sciences) }\end{array}$ & \begin{tabular}{|c} 
VOSviewer \\
software \\
PredicTER \\
Software \\
CADIMA \\
Software \\
NVivo 12 Plus \\
Software \\
Zotero \\
Software \\
\end{tabular} \\
\hline $\begin{array}{c}\text { Unhealthy diets, obesity and } \\
\text { time discounting: a systematic } \\
\text { literature review and network } \\
\text { analysis } \\
\text { (Barlow et al. 2016) }\end{array}$ & $\checkmark$ & I & I & 1 & (Medicine) & $\begin{array}{l}\text { VOSviewer } \\
\text { software }\end{array}$ \\
\hline
\end{tabular}




\begin{tabular}{|c|c|c|c|c|c|c|}
\hline $\begin{array}{c}\text { Entrepreneurship in island } \\
\text { contexts: A systematic review } \\
\text { of the tourism and hospitality } \\
\text { literature } \\
\text { (Booth et al. 2020) }\end{array}$ & I & $\checkmark$ & I & I & (Social Sciences) & $\begin{array}{l}\text { NVivo } 11 \\
\text { software }\end{array}$ \\
\hline $\begin{array}{c}\text { Precision Techniques and } \\
\text { Agriculture } 4.0 \text { Technologies } \\
\text { to Promote Sustainability in } \\
\text { the Coffee Sector: State of the } \\
\text { Art, Challenges and Future } \\
\text { Trends } \\
\text { (Sott et al. 2020) }\end{array}$ & I & $\checkmark$ & I & I & $\begin{array}{c}\text { (Computer } \\
\text { Science) } \\
\text { (Engineering) } \\
\text { (Telecommunicatio } \\
\mathrm{ns})\end{array}$ & $\begin{array}{l}\text { SciMAT } \\
\text { software }\end{array}$ \\
\hline $\begin{array}{l}\text { The } 100 \text { top-cited systematic } \\
\text { reviews/meta-analyses in } \\
\text { central venous catheter } \\
\text { research: A PRISMA- } \\
\text { compliant systematic literature } \\
\text { review and bibliometric } \\
\text { analysis } \\
\text { (Huang, Chen, and Liu 2020) }\end{array}$ & l & $\checkmark$ & l & I & (Nursing) & \\
\hline $\begin{array}{c}\text { A Systematic Literature } \\
\text { Review Paper on Online } \\
\text { Medical Mobile Applications in } \\
\text { Malaysia } \\
\text { (Khan et al. 2020) }\end{array}$ & I & $\checkmark$ & I & I & $\begin{array}{l}\text { (Computer } \\
\text { Science) }\end{array}$ & $\begin{array}{l}\text { Microsoft } \\
\text { excel }\end{array}$ \\
\hline $\begin{array}{l}\text { What happens after the Rare } \\
\text { Earth Crisis: a systematic } \\
\text { literature review } \\
\text { (Chen and Zheng 2019) }\end{array}$ & l & $\checkmark$ & 1 & I & $\begin{array}{l}\text { (Environmental } \\
\text { Science Ecology) } \\
\text { (Science and } \\
\text { technology) }\end{array}$ & $\begin{array}{c}\text { Microsoft } \\
\text { excel }\end{array}$ \\
\hline $\begin{array}{c}\text { Responses to President } \\
\text { Trump ' s rumoured executive } \\
\text { order on research publication } \\
\text { policy. } \\
\text { (Colclough and Colclough } \\
\text { n.d.) }\end{array}$ & / & 1 & $\checkmark$ & / & & $\begin{array}{l}\text { VOSviewer } \\
\text { software } \\
\text { NodeXL } \\
\text { NVivo } \\
\text { software }\end{array}$ \\
\hline $\begin{array}{c}\text { The Rise of Digital Business } \\
\text { Models: An Analysis of the } \\
\text { Knowledge Base } \\
\text { (Schaller et al. 2019) }\end{array}$ & $\checkmark$ & $\checkmark$ & $\checkmark$ & I & $\begin{array}{l}\text { (Business, } \\
\text { Management and } \\
\text { Accounting) } \\
\text { (Computer } \\
\text { Science) } \\
\text { (Decision } \\
\text { Sciences) } \\
\text { (Engineering) }\end{array}$ & $\begin{array}{l}\text { VOSviewer } \\
\text { software }\end{array}$ \\
\hline $\begin{array}{c}\text { Digital Transformation in } \\
\text { Higher Education Institutions: } \\
\text { A Systematic Literature } \\
\text { Review } \\
\text { (Castro Benavides et al. 2020) }\end{array}$ & $\checkmark$ & $\checkmark$ & $\checkmark$ & I & $\begin{array}{l}\text { (Biochemistry, } \\
\text { Genetics and } \\
\text { Molecular Biology) } \\
\text { (Chemistry) } \\
\text { (Engineering) } \\
\text { (Physics and } \\
\text { Astronomy) }\end{array}$ & $\begin{array}{l}\text { Mendeley and } \\
\text { Microsoft } \\
\text { Excel. } \\
\text { Gephi } \\
\text { software }\end{array}$ \\
\hline $\begin{array}{c}\text { Financial Technology: Review } \\
\text { of Trends, Approaches and } \\
\text { Management } \\
\text { (Abad-Segura, González- } \\
\text { Zamar, López-Meneses, et al. } \\
\text { 2020) }\end{array}$ & $\checkmark$ & $\checkmark$ & $\checkmark$ & I & (Mathematics) & $\begin{array}{l}\text { VOSviewer } \\
\text { software }\end{array}$ \\
\hline
\end{tabular}




\begin{tabular}{|c|c|c|c|c|c|c|}
\hline $\begin{array}{l}\text { Sustainability of Educational } \\
\text { Technologies: An Approach to } \\
\text { Augmented Reality Research } \\
\text { (Abad-Segura, González- } \\
\text { Zamar, Rosa, et al. 2020) }\end{array}$ & $\checkmark$ & $\checkmark$ & $\checkmark$ & 1 & $\begin{array}{l}\text { (Energy) } \\
\text { (Environmental } \\
\text { Science) (Social } \\
\text { Sciences) }\end{array}$ & $\begin{array}{l}\text { VOSviewer } \\
\text { software }\end{array}$ \\
\hline $\begin{array}{l}\text { A bibliometric review of the } \\
\text { knowledge base for innovation } \\
\text { in sustainable development } \\
\text { (Vatananan-Thesenvitz, } \\
\text { Schaller, and Shannon 2019) }\end{array}$ & I & 1 & $\checkmark$ & 1 & $\begin{array}{c}\text { social science, } \\
\text { business, and } \\
\text { decision making. }\end{array}$ & $\begin{array}{l}\text { VOSviewer } \\
\text { software }\end{array}$ \\
\hline $\begin{array}{l}\text { Insights for the future of health } \\
\text { system partnerships in low- } \\
\text { and middle-income countries: } \\
\text { a systematic literature review } \\
\text { (Fanelli et al. 2020) }\end{array}$ & I & 1 & 1 & $\checkmark$ & $\begin{array}{c}\text { Medicine } \\
\text { Public Health }\end{array}$ & $\begin{array}{l}\text { VOSviewer } \\
\text { software }\end{array}$ \\
\hline $\begin{array}{l}\text { Life cycle modeling for } \\
\text { environmental management: a } \\
\text { review of trends and linkages } \\
\text { (Sharma and Gupta 2020) }\end{array}$ & I & 1 & I & $\checkmark$ & Environment & $\begin{array}{l}\text { VOSviewer } \\
\text { software }\end{array}$ \\
\hline $\begin{array}{l}\text { Why and how to merge } \\
\text { Scopus and Web of Science } \\
\text { during bibliometric analysis: } \\
\text { the case of sales force } \\
\text { literature from } 1912 \text { to } 2019 \\
\text { (Echchakoui 2020) }\end{array}$ & I & I & I & $\checkmark$ & $\begin{array}{l}\text { Business and } \\
\text { Management }\end{array}$ & $\begin{array}{l}\text { VOSviewer } \\
\text { software } \\
\text { Excel }\end{array}$ \\
\hline
\end{tabular}

The papers were reviewed and separated into different categories. The studies by (de Campos et al. 2017; Echchakoui 2020) were categorised as management and business research; the studies by (Pulsiri et al., 2019; Schaller et al., 2019; Schaller \& Vatananan-Thesenvitz, 2019) were classified into management and business research, computer science, decision sciences and engineering; the studies by (Araújo et al. 2020; Castelein et al. 2020) were grouped into management and business research, energy, engineering, and environmental science; the studies by (Corallo et al. 2020) were grouped into management and business research, decision sciences, and engineering, and the study by (Teniwut and Hasyim 2020) was classified into management and business research, and decision sciences. Only one study (Vatananan-Thesenvitz et al. 2019) dealt with business and social science research.

All studies used the PRISMA model to clarify the search criteria and identify the sources and bibliometric analysis using VOSviewer software to discover the knowledge base of the research scope.

The PRISMA guideline developed by (Moher et al., 2009) comprises four main phases: identification, screening, eligibility, and inclusion. The purpose of the PRISMA model aims to help authors improve the reporting of systematic reviews and meta-analyses and summarise the existing evidence in an accurate, and transparent step-by-step or staged process. The PRISMA guideline describes all information sources in the search process to present the electronic search strategy for at least one database and illustrate the study selection process. (Cañas-Guerrero et al., 2014; Hansen et al., 2015; Mardani et al., 2017; Moher et al., 2009, Qureshi et al. 2020) used the PRISMA guideline for the identification of relevant literature.

Bibliometrics applies statistics and quantitative analysis to assess research and publication performance linked to authors, countries, institutions and using science mapping analysis to examine and visualise the structure of knowledge and development of research fields (Borgman and Furner 2002; Noyons, Moed, and Luwel 1999; Zou, Yue, and Le Vu 2018). Such analysis allows constructing a network based on the relationships between countries, journals, organisations, authors, and keywords dealing with the topic under investigation (Chen et al. 2016). According to (Zupic and Čater 2015), bibliometric reviews help to obtain a comprehensive overview of the network and the structure of a research area. 
On the other hand, VOSviewer is one of the most widely utilised open-source tools for visualising and creating bibliometric maps. The notion behind the VOSviewer mapping technique is to create mappings of keywords or clusters with the greatest recurrence or frequency (Van Eck and Waltman 2014). Clustering has the added advantage that objects are grouped based on similarity or dissimilarity (Ravikumar, Agrahari, and Singh 2015). Hence, it should be noted that each element can only be included in one cluster (Eck and Waltman 2020). Also, the distance between two elements (i.e. nodes) reflects the strength of the relationship between them; for example, a shorter distance means a stronger relationship. Besides, the nodes' size represents their weight, and the line between two nodes shows their co-occurrence and the frequency of appearing together. The line's thickness represents the degree of this frequency (Eck and Waltman 2020).

The studies by (Echchakoui 2020; Teniwut and Hasyim 2020) employed Microsoft Excel with VOSviewer, and (Teniwut and Hasyim 2020) used Microsoft Excel to remove duplicate publications. (Echchakoui 2020) applied Microsoft Excel to process data collection according to the research question while (Castelein et al. 2020) utilised the Covidence systematic review software to track the steps associated with the systematic review process including all inclusions/exclusions, and Gephi and VOSviewer software to visualise the data.

Additionally, the studies by (Schaller et al. 2019; Schaller and Vatananan-Thesenvitz 2019) followed the approach of (Gerdsri, Kongthon, and Vatananan 2013; Hallinger and Suriyankietkaew 2018; Kovačević and Hallinger 2019; Moher et al. 2009; Zupic and Čater 2015), and (Schaller et al. 2019; Schaller and Vatananan-Thesenvitz 2019) initially formulated the research questions. As the second step, the PRISMA guidelines were then used to assess the search standards and identify the source. In the third step, scientific mapping research using bibliometric methods was performed in which bibliometric analysis and visualisations were undertaken with the VOSviewer software. The final step involves interpreting and reporting the results according to the research questions. (Zupic and Čater 2015) asserted that science mapping methods have the potential to enhance the quality of the review through systematic, transparent, and reproducible analysis, while the bibliometric software tools perform bibliometric calculations and compute the similarity matrices between the elements.

The studies by (Abad-Segura, González-Zamar, Rosa, et al. 2020; Corallo et al. 2019; Konys 2019; Koren and Rus 2019; Niñerola et al. 2020; Valverde-Berrocoso et al. 2020; Vrchota et al. 2020) were all grouped into energy, environmental sciences, and social sciences areas. The study by (Wang et al. 2019) was grouped into arts and humanities, and social science research. In contrast, the study by (Booth et al. 2020) was classified as a social science study.

All studies applied the PRISMA model and bibliometric analysis. For instance, the studies by (Booth et al. 2020; Valverde-Berrocoso et al. 2020; Vrchota et al. 2020) employed content analysis, whereas the study by (Vrchota et al. 2020) used the acronym PICO. The PICO-procedure is an effective means to formulate the eligibility criteria in systematic reviews, based on the contexts of the problem, intervention, comparison, and outcomes (Amir-Behghadami and Janati 2020).

In all studies, VOSviewer software was used to analyse the data, except for the study by (Booth et al. 2020) which employed NVivo software. NVivo is a qualitative data analysis tool used to store, systematise, and encode the content of data (Bazeley and Jackson 2013). (Vrchota et al. 2020) in their study used Microsoft Excel to create and develop a coding frame for content analysis. The Endnote software database was also used to upload all citations and abstracts identified by the search strategy and conduct record filtering based on the defined filter criteria. Further to that, (Valverde-Berrocoso et al. 2020) selected the online software (PredicTER and VOSviewer) in estimating the total duration of the verification process, using Zotero software to compile and manage documentation databases, and also the CADIMA software to enable data extraction in meeting PRISMA's standards. NVivo 12 Plus was also employed to extract the data and generate categories and sub-categories. 
Table 3: Search result in the databases Scopus

\begin{tabular}{|c|c|c|}
\hline Article & SRL Steps & Analysis Software \\
\hline $\begin{array}{l}\text { The digital transformation of business } \\
\text { models in the creative industries: A } \\
\text { holistic framework and emerging } \\
\text { trends } \\
\text { (Li 2020) }\end{array}$ & $\begin{array}{l}\text { - Use the ISI Web of Knowledge } \\
\text { - A systematic search of relevant } \\
\text { publications } \\
\text { - A multi-staged filtering process } \\
\text { - key references from known authorities on } \\
\text { the subject were identified. }\end{array}$ & l \\
\hline $\begin{array}{l}\text { A Systematic Analysis and Synthesis } \\
\text { of Case Study Based Agile Scaling } \\
\text { Research in the Context of Digital } \\
\text { Transformations } \\
\text { (Limaj and Bernroider 2019) }\end{array}$ & $\begin{array}{l}\text { - Choosing research databases } \\
\text { - Databases search } \\
\text { - Reference search } \\
\text { - Title abstract assessment } \\
\text { - Full paper assessment } \\
\text { - Content review }\end{array}$ & NVIVO \\
\hline $\begin{array}{l}\text { A systematic literature review on } \\
\text { digital transformation } \\
\text { (Gebayew et al. 2018) }\end{array}$ & $\begin{array}{l}\text { - Research Question } \\
\text { - Research Identification } \\
\text { - Study Selection } \\
\text { - Inclusion and Exclusion Criteria } \\
\text { - Quality Assessment } \\
\text { - Data collection } \\
\text { - Data Analysis (descriptive analysis in) }\end{array}$ & descriptive analysis \\
\hline $\begin{array}{l}\text { A Systematic literature review of } \\
\text { Digital Transformation } \\
\text { (Mahraz et al. 2019) }\end{array}$ & $\begin{array}{l}\text { - Planning: (Research Identification) } \\
\text { - Selection:( Research Strategy and Study } \\
\text { Selection) } \\
\text { - Extraction: (Quality appraisal and Data } \\
\text { Extraction) } \\
\text { - Data execution: (Data synthesis and } \\
\text { Qualitative analysis) }\end{array}$ & $\begin{array}{l}\text { quantitative and } \\
\text { qualitative analysis } \\
\text { Bibliometric review } \\
\text { by using "Publish or } \\
\text { Perish" }\end{array}$ \\
\hline $\begin{array}{l}\text { The future of personal urban mobility- } \\
\text {-towards digital transformation } \\
\text { (Piccinini et al. 2016) }\end{array}$ & $\begin{array}{l}\text { - } \text { choosing databases } \\
\text { - } \text { elaborate a search keyword matrix } \\
\text { - Databases search } \\
\text { - data selection } \\
\text { - Title abstract assessment (Inclusion and } \\
\text { - } \text { bxclusion) } \\
\text { backward and forward search }\end{array}$ & l \\
\hline $\begin{array}{l}\text { Enhancing citizens' trust and } \\
\text { confidence in government through } \\
\text { digital transformation } \\
\text { (Mahmood 2016) }\end{array}$ & & l \\
\hline $\begin{array}{l}\text { Research streams on digital } \\
\text { transformation from a holistic } \\
\text { business perspective: a systematic } \\
\text { literature review and citation network } \\
\text { analysis } \\
\text { (Hausberg et al. 2019) }\end{array}$ & $\begin{array}{l}\text { - } \text { Identification of literature } \\
\text { - } \text { Citation network analysis } \\
\text { - } \text { Qualitative analysis }\end{array}$ & $\begin{array}{l}\text { Excel } \\
\text { Gephi }\end{array}$ \\
\hline $\begin{array}{l}\text { Contextual impacts on industrial } \\
\text { processes brought by the digital } \\
\text { transformation of manufacturing: A } \\
\text { systematic review } \\
\text { (Savastano et al. 2019) }\end{array}$ & $\begin{array}{l}\text { - Preparation } \\
\text { - Search } \\
\text { - Selection } \\
\text { - Analysis/ Results }\end{array}$ & $\begin{array}{l}\text { Mendeley } \\
\text { Excel } \\
\text { R software }\end{array}$ \\
\hline
\end{tabular}


Our search in the Scopus database identified several systematic literature reviews on digital transformation related to business and social sciences. The following search in the Scopus database was considered for this task: (TITLE ("Digital Transformation") AND TITLE-ABS-KEY ("systematic literature review") OR TITLE-ABS-KEY ("SLR") OR TITLE-ABS-KEY ("systematic mapping") OR TITLE-ABSKEY ("structure literature review") AND (LIMIT-TO (SUBJAREA, "BUSI") OR LIMIT-TO (SUBJAREA, "SOCI")). As a result, eight SLR articles were discovered. Table 3 shows the methodology and software utilised in these articles.

The summary of the various articles revealed that only the articles by (Hausberg et al. 2019; Mahraz et al. 2019; Savastano et al. 2019) performed bibliometric analysis; none applying the PRISMA model. The types of software used included Mendeley, Microsoft Excel, R software, Gephi, Publish or Perish, and NVIVO.

This study develops a systematic literature review procedure using bibliometric analysis, prima model, and analysis software programs based on the presented comparison above. The developed procedure integrates the PRISMA guidelines (Preferred Reporting Items for Systematic Reviews and Meta-Analysis) developed by (Moher et al. 2009) into the bibliometric standard workflow proposed by (Zupic and Čater 2015) and uses Biblioshiny, VOSviewer, and NVIVO software as tools. The developed method also contributes to the systematic review method in business and social science research, especially in the field of digital transformation. The proposed procedure integrates the PRISMA guidelines into the standard bibliometric workflow to improve and facilitate the identification process of the relevant literature, and it applies Biblioshiny, VOSviewer, and NVivo software to organise the paper and improve the extraction, visualisation, and analysis of data. The proposed procedures consist of four stages, as shown in Figure 1.

Figure 1: The proposed procedure for systematic literature review

\begin{tabular}{|c|c|}
\hline \multicolumn{3}{|c|}{ Stage 1: Research design } \\
\hline Research Question & Method \\
\hline \multicolumn{3}{|c|}{ Stage 2: Data collection } \\
\hline \multicolumn{3}{|c|}{ Selection of database } \\
\hline \multicolumn{3}{|c|}{ 1st phase: identification } \\
Selected keywords
\end{tabular}




\section{The proposed systematic literature review stages}

The procedure shown in Figure 1 was used to apply a systematic literature search in the field of digital transformation in business and social research in this study (see Figure 2).

Figure 2: systematic literature search in the field of digital transformation in business and social science research

\begin{tabular}{|c|c|c|c|}
\hline \multicolumn{4}{|c|}{ Stage 1: Research Design } \\
\hline \multicolumn{3}{|r|}{ Research Question } & Method \\
\hline RQ1 & \multicolumn{2}{|c|}{$\begin{array}{l}\text { What are the most influential articles, authors, and countries for digital } \\
\text { transformation in management, Social sciences, Econometrics, and } \\
\text { Finance? }\end{array}$} & $\begin{array}{l}\text { descriptive } \\
\text { bibliometric } \\
\text { analysis }\end{array}$ \\
\hline RQ2 & \multicolumn{2}{|c|}{$\begin{array}{l}\text { What are the future research directions for digital transformation in } \\
\text { management, Social sciences, Econometrics and Finance? }\end{array}$} & $\begin{array}{l}\text { science mapping } \\
\text { content analysis }\end{array}$ \\
\hline \multicolumn{4}{|c|}{ Collection } \\
\hline \multicolumn{3}{|c|}{ Selection of database } & Elsevier's Scopus \\
\hline \multicolumn{4}{|c|}{ 1st phase: identification } \\
\hline \multicolumn{2}{|c|}{ Selected keywords } & "Digital Transformation" (all fields) & 10832 \\
\hline \multicolumn{4}{|c|}{ 2nd Phase: Screening } \\
\hline \multicolumn{2}{|c|}{ Search restriction } & Article Title & 1262 \\
\hline \multicolumn{2}{|c|}{ Period of search } & From 2010 to June 2020 & 1229 \\
\hline \multicolumn{2}{|c|}{ Language } & English & 1135 \\
\hline \multicolumn{2}{|c|}{ Source type } & Journal & 439 \\
\hline \multicolumn{2}{|c|}{ Document type } & Article & 350 \\
\hline \multicolumn{2}{|c|}{ Major subject areas } & $\begin{array}{l}\text { Business, management, and accounting; Social sciences, } \\
\text { Economics, Econometrics and Finance }\end{array}$ & 238 \\
\hline \multicolumn{2}{|c|}{ Keywords } & Digital Transformation & 120 \\
\hline \multicolumn{4}{|c|}{ 3rd Phase: Eligibility } \\
\hline \multicolumn{2}{|c|}{$\begin{array}{l}\text { Title, Abstract assessed } \\
\text { for eligibility }\end{array}$} & $\begin{array}{l}\text { PICO criteria (population, intervention, comparators, } \\
\text { outcome) }\end{array}$ & 66 \\
\hline \multicolumn{2}{|c|}{$\begin{array}{l}\text { Full-text articles } \\
\text { assessed for eligibility }\end{array}$} & $\begin{array}{l}\text { Exclusion criteria: only document type article that } \\
\text { published in English is analyze, duplicate articles are } \\
\text { excluded. Incomplete copies of articles were removed, } \\
\text { articles that do not focus on DT content are excluded. }\end{array}$ & 41 \\
\hline \multicolumn{4}{|c|}{ 4th Phase: Inclusion } \\
\hline \multicolumn{2}{|c|}{ Articles included } & Remaining articles & 41 \\
\hline \multicolumn{4}{|c|}{ Stage 3: Data Analysis } \\
\hline \multicolumn{2}{|c|}{ Research Question } & Analysis Method & Analysis software \\
\hline \multicolumn{2}{|r|}{ RQ1 } & Descriptive bibliometric analysis & Biblioshiny \\
\hline \multicolumn{2}{|r|}{ RQ2 } & Bibliographical coupling, Content analysis & VOSviewer, NVivo \\
\hline \multicolumn{4}{|c|}{ Stage 4: Visualization } \\
\hline \multicolumn{2}{|c|}{ Research Question } & Visualization method & Visualization tool \\
\hline & RQ1 & $\begin{array}{l}\text { Graphics and Tables (publications and citation } \\
\text { distributions) }\end{array}$ & Biblioshiny \\
\hline & RQ2 & $\begin{array}{l}\text { document bibliographic coupling network, Content } \\
\text { analysis }\end{array}$ & $\begin{array}{l}\text { VOSviewer } \\
\text { NVivo }\end{array}$ \\
\hline
\end{tabular}

The SLR process consisted of four phases (research design, data collection, data analysis, and visualisation) using three software programs (Biblioshiny, VOSviewer, and NVivo) as tools to organise 
the papers and extract the data (refer to Figure 2). Biblioshiny was utilised to conduct the descriptive bibliometric analysis, which visualises data through graphics and tables (Anon n.d.). VOSviewer was also used to cluster publications, and NVivo 12 Plus qualitative software was employed for content analysis generating themes to classify the research variables. The data passed by the coding process was then used to identify and categorise the variables in this study.

As the initial step in designing this study, the research questions were formulated, before choosing the appropriate bibliometric methods. The research questions included: (RQ1) What are the most influential articles, authors, and countries for digital transformation in Management, Social sciences, Econometrics, and Finance?; (RQ2) What are the future research directions for digital transformation in Management, Social Sciences, Econometrics, and Finance?

Descriptive bibliometric analysis was used to discover annual publication trends and the most influential articles, authors, and countries in the field. Second, bibliographical coupling was implemented to visualise recent research streams (clusters) in this area. Finally, future research directions were determined by analysing the content of all articles in a cluster.

The second step involved the collection of bibliometric data that included database selection, filtering, and the refinement of the bibliographic data. Here the Scopus database was used. In selecting the publications, PRISMA guidelines were used, consisting of four main phases: identification, screening, eligibility, and inclusion.

In the first phase (Identification), a literature search was performed using the Scopus database with the keyword "Digital Transformation", searched in all fields. The keyword "Digital Transformation" was used given it was the phenomenon associated with the investigation.

In the second phase (Screening), the option "Article title" was selected in the field of "Digital Transformation" excluding 9,570 data records. The remaining 1,262 items were then screened based on the following criteria: (1) Timeline, (2) Language, (3) Source type (4) Document type (5) Categories, and (6) Keywords. This review only focused on journal articles published in English. The document search was confined to the period between 2010 and 2020, with the research area restricted to social science and business studies. After applying the criteria, 1,142 items were excluded from the study, with120 eligible papers remaining.

In the third phase (Eligibility), the quality criteria were defined to evaluate the selected articles. The process of including and excluding articles was as follows. First, PICO criteria (population, intervention, comparators, and outcome) were applied to the papers based on their title and abstract, namely, (1) Population: management and social science research; (2) Intervention: the phenomenon of digital transformation in management and social science research; (3) Comparison: in this study, no comparison intervention had been projected, and (4) Outcomes: current structure of the phenomenon of digital transformation in management and social science research. Next, the articles were assessed for eligibility by full-text reading based on (1) Language: only articles published in English were selected; (2) Setting: restrictions by document type; the articles were analysed to guarantee the quality derived from the peer-review process; (3) Duplicate: repeated articles were excluded; (4) Incomplete copies of articles were removed, and (5) Paper content (mainly introduction and conclusion): excluding publications that did not focus on digital transformation in the areas of Management, Social Sciences, Econometrics and Finance. Studies to identify further dimensions: strategies, goals, processes, methods, technologies, business models, and actors of the digital transformation process in institutions were added, including studies that described methods for implementing digital transformation in institutions. In this phase, 79 documents were omitted with 41 records identified and included in the last phase (Inclusion).

The third step (data analysis) began with describing the main bibliometric statistics to gain a sense of the relative standing of the digital transformation in the fields of social sciences and management. Descriptive bibliometric analysis was used in answering (RQ1). The descriptive bibliometric analysis enabled identifying trends in literature, distribution of document types, the most productive authors, organisations, and countries. The biblioshiny tool was used here to analyse the data and visualises it 
using graphics and tables, (e.g. main information on selected articles) (see Table 4), the most frequently cited articles worldwide (see Table 5), the most productive countries (see Table 6), and the annual scientific production (see Figure 3).

(RQ2) was answered using Bibliographic coupling to identify recent research clusters, collect documents in the current research field, and then use content analysis to determine and analyse future research streams of all articles in a cluster. Therefore, VOSviewer software was selected to examine the data (see Figure 4). For content analysis, NVivo was used (see Figure 5).

Lastly, in the fourth step of visualisation Biblioshiny, VOSviewer and NVivo were used to analyse and visualise the data set for digital transformation for the period between 2010 and 2020 in the academic literature on Management, Social Sciences, Econometrics, and Finance.

\section{Reporting}

Reporting on the dataset using Biblioshiny, VOSviewer, and NVivo software are reflected in the following tables and figures (see Table 4,5,6 and Figure 3,4,5).

Table 4: Main information on selected articles. Source: Biblioshiny

\begin{tabular}{|l|c|}
\hline Description & Results \\
\hline Timespan & $2017: 2020$ \\
\hline Documents & 34 \\
\hline Average years from publication & 41 \\
\hline Average citations per document & $/$ \\
\hline References & $/$ \\
\hline Articles & $/$ \\
\hline Authors & $/$ \\
\hline Authors of single-authored documents & $/$ \\
\hline Single-authored documents & $/$ \\
\hline Authors per Document & $/$ \\
\hline Co-Authors per Document & $/$ \\
\hline
\end{tabular}

Table 5: The most global cited papers. Source: Biblioshiny

\begin{tabular}{|l|l|c|c|}
\hline No & Paper & TC & TC/ year \\
\hline 1 & WARNER KSR, 2019, LONG RANGE PLANN & 29 & 14.50 \\
\hline 2 & HEAVIN C, 2018, J DECIS SYST & 26 & 8.67 \\
\hline
\end{tabular}

Table 6: Most productive countries. Source: Biblioshiny

\begin{tabular}{|l|c|}
\hline Country & No. of paper \\
\hline GERMANY & 12 \\
\hline BRAZIL & 8 \\
\hline
\end{tabular}


Figure 3. Annual Scientific Production: Biblioshiny

\section{Annual Scientific Production}

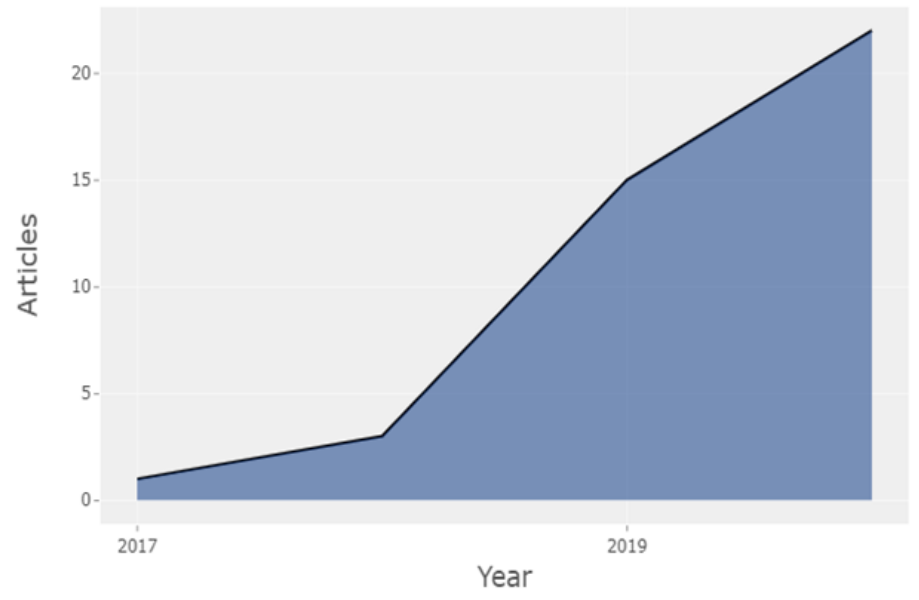

Figure 4. Bibliographic coupling of 36 digital transformation: Vosviewer

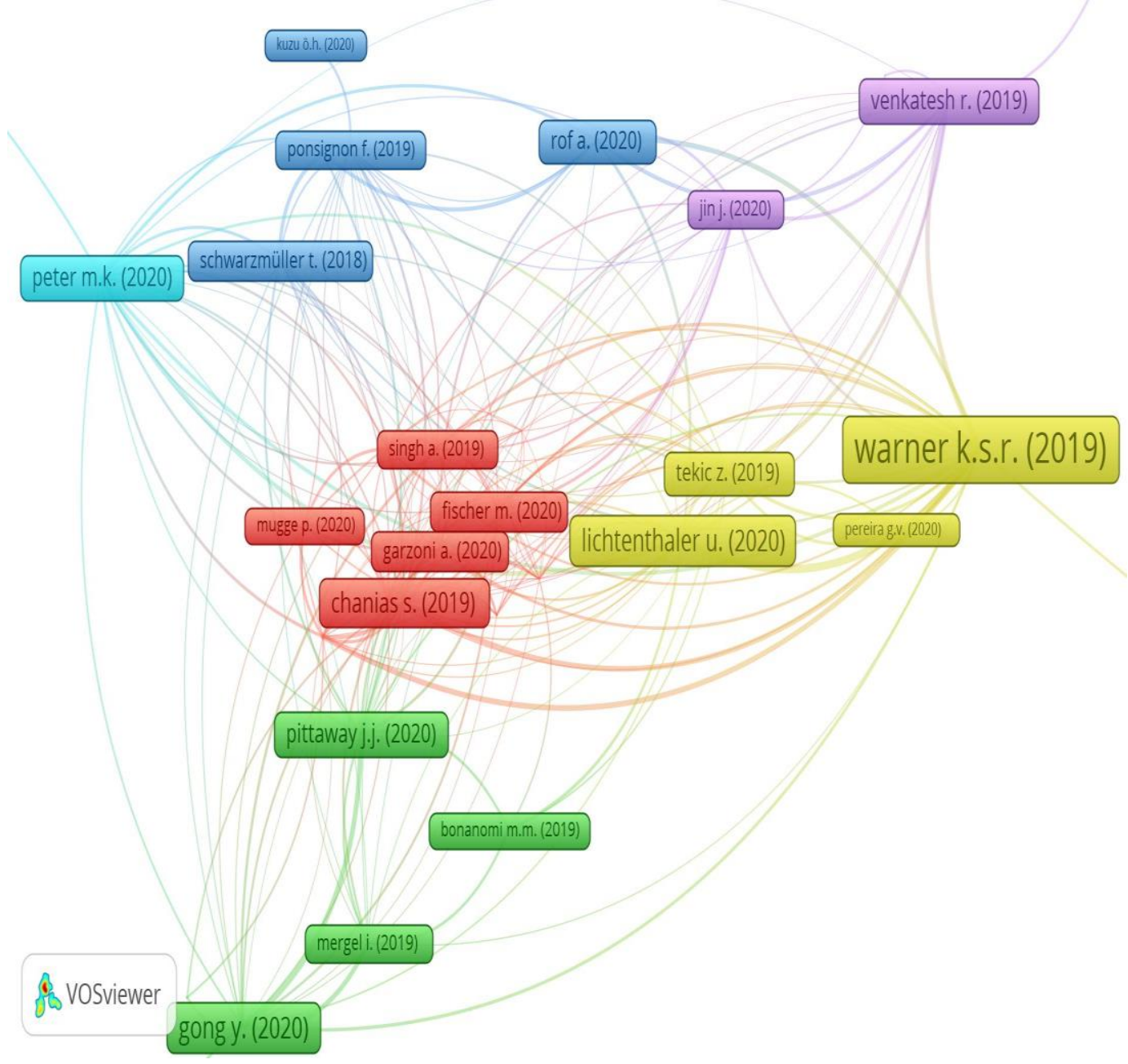


Figure 5. Themes and Nodes tree for this review: NVivo

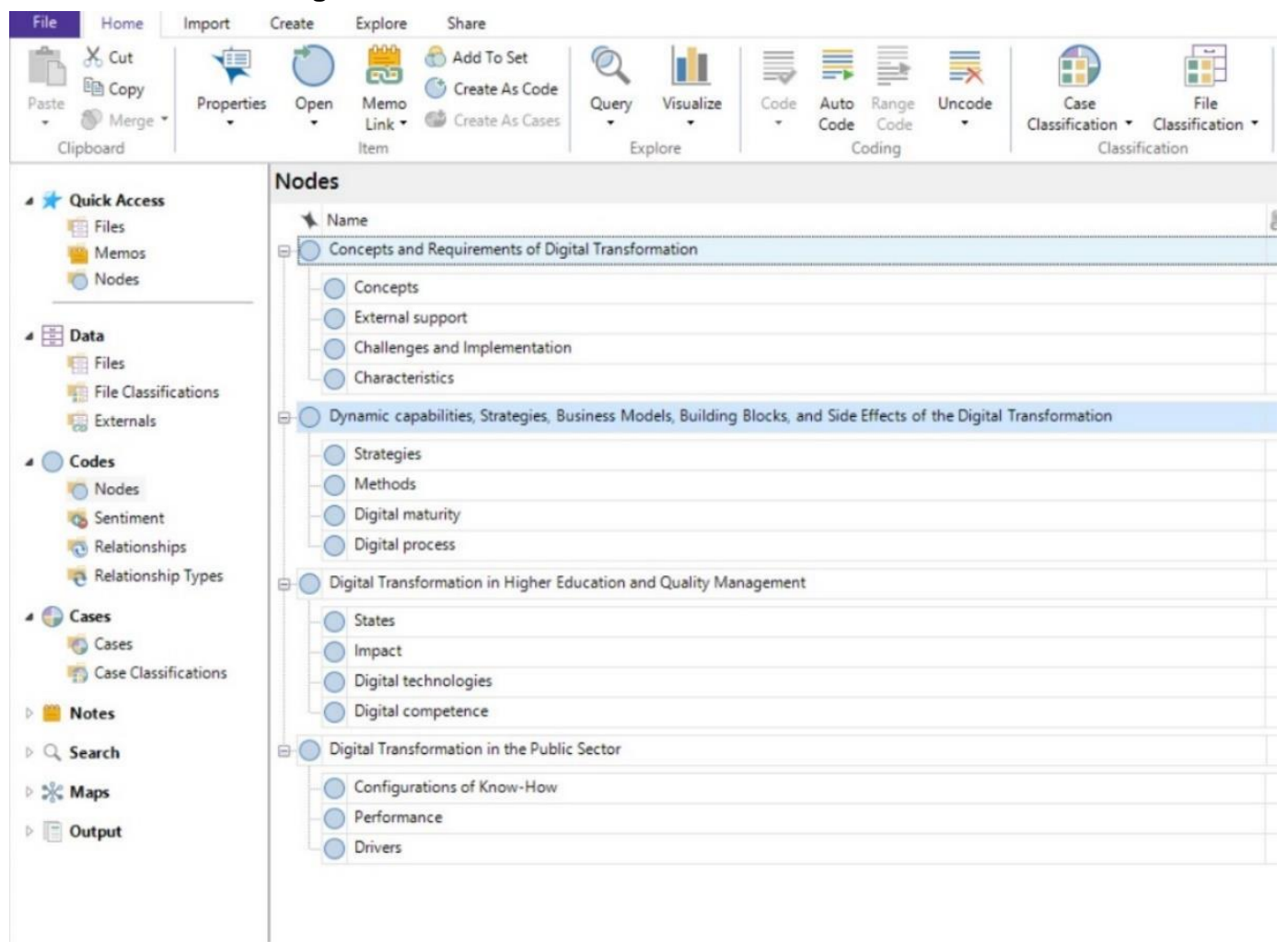

\section{Conclusion}

In this paper, we have developed a systematic literature review procedure based on the bibliometric standard workflow proposed by (Zupic and Čater 2015), and a systematic review in the field of digital transformation in business and social science research was performed to validate and apply the developed procedure. PRISMA guidelines, developed by (Moher et al. 2009), were incorporated into the bibliometric standard workflow to establish filters to identify relevant literature. Biblioshiny software was also used to conduct descriptive bibliometric analysis, VOSviewer for science mapping analysis, and NVivo software for content analysis. We suggest a procedure that consists of four phases in undertaking the systematic review: research design, data collection, data analysis, and visualisation. The developed method offers an effective process for systematic literature review in the field of business and social science. The use of software programs also facilitates and improves the extraction, visualisation, and analysis of data. This study contributes to the systematic review method in business and social science research, principally in the field of digital transformation.

\section{Acknowledgement}

The authors are grateful for access to data tools provided by Azman Hashim International Business School (AHIBS), UTM and MOHE, Malaysia in conducting this research.

\section{Referencias}

1. Abad-Segura, Emilio, Mariana-Daniela González-Zamar, Eloy López-Meneses, and Esteban VázquezCano. 2020. "Financial Technology: Review of Trends, Approaches and Management." Mathematics $8(6): 951$.

2. Abad-Segura, Emilio, Mariana-Daniela González-Zamar, Antonio Luque-de la Rosa, and Mar\’\ia Belén Morales Cevallos. 2020. "Sustainability of Educational Technologies: An Approach to Augmented Reality Research." Sustainability 12(10):4091. 
3. Alsolami, B., and M. R. Embi. 2018. "Crowding Perception: A Case Study of Developed Systematic Literature Review Procedure with Multiple Software Programs as Management and Synthesis Tools,(April)." International Journal of Engineering \& Technology 7(2.10):121-26.

4. Amir-Behghadami, Mehrdad, and Ali Janati. 2020. "Population, Intervention, Comparison, Outcomes and Study (PICOS) Design as a Framework to Formulate Eligibility Criteria in Systematic Reviews." Emergency Medicine Journal: EMJ.

5. Anon. n.d. "Biblioshiny."

6. Araújo, Adolpho Guido, Arnaldo Manoel Pereira Carneiro, Rachel Perez Palha, Arnaldo Manoel, Pereira Carneiro, and Rachel Perez Palha. 2020. "Sustainable Construction Management: A Systematic Review of the Literature with Meta-Analysis." Journal of Cleaner Production 256:120350.

7. Barlow, Pepita, Aaron Reeves, Martin McKee, Gauden Galea, and David Stuckler. 2016. "Unhealthy Diets, Obesity and Time Discounting: A Systematic Literature Review and Network Analysis." Obesity Reviews 17(9):810-19.

8. Bazeley, Patricia, and Kristi Jackson. 2013. Qualitative Data Analysis with NVivo. SAGE publications limited.

9. Booth, Paul, Samantha A. Chaperon, James S. Kennell, and Alastair M. Morrison. 2020. "Entrepreneurship in Island Contexts: A Systematic Review of the Tourism and Hospitality Literature." International Journal of Hospitality Management 85:102438.

10.Borgman, Christine L., and Jonathan Furner. 2002. "Scholarly Communication and Bibliometrics." Annual Review of Information Science and Technology 36(1):1-53.

11.de Campos, Elaine Aparecida Regiani, Istefani Carisio de Paula, Regina Negri Pagani, and Patricia Guarnieri. 2017. "Reverse Logistics for the End-of-Life and End-of-Use Products in the Pharmaceutical Industry: A Systematic Literature Review." Supply Chain Management: An International Journal.

12.Cañas-Guerrero, Ignacio, Fernando R. Mazarrón, Cruz Calleja-Perucho, and Ana Pou-Merina. 2014. "Bibliometric Analysis in the International Context of the 'Construction \& Building Technology' Category from the Web of Science Database." Construction and Building Materials 53:13-25.

13.Castelein, Bob, Harry Geerlings, and Ron Van Duin. 2020. "The Reefer Container Market and Academic Research: A Review Study." Journal of Cleaner Production 120654.

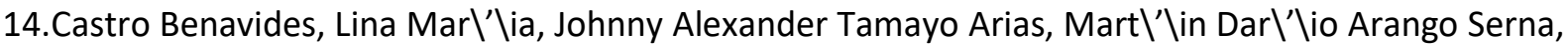
John William Branch Bedoya, and Daniel Burgos. 2020. "Digital Transformation in Higher Education Institutions: A Systematic Literature Review." Sensors 20(11):3291.

15.Chen, Dan, Zhi Liu, Zhaohui Luo, Michael Webber, and Jing Chen. 2016. "Bibliometric and Visualized Analysis of Emergy Research." Ecological Engineering 90:285-93.

16.Chen, Yufeng, and Biao Zheng. 2019. "What Happens after the Rare Earth Crisis: A Systematic Literature Review." Sustainability (Switzerland) 11(5):1288.

17.Colclough, Martin, and Martin Colclough. n.d. "Responses to President Trump 's Rumoured Executive Order on Research Publication Policy."

18.Corallo, Angelo, Maria Elena Latino, Marta Menegoli, Biagia De Devitiis, and Rosaria Viscecchia. 2019. "Human Factor in Food Label Design to Support Consumer Healthcare and Safety: A Systematic Literature Review." Sustainability 11(15):4019.

19.Corallo, Angelo, Maria Elena Latino, Marta Menegoli, and Pierpaolo Pontrandolfo. 2020. "A Systematic Literature Review to Explore Traceability and Lifecycle Relationship." International Journal of Production Research 1-19.

20.Creswell, John W., and J. David Creswell. 2017. Research Design: Qualitative, Quantitative, and Mixed Methods Approaches. Sage publications.

21.Echchakoui, Sa\"\id. 2020. "Why and How to Merge Scopus and Web of Science during Bibliometric Analysis: The Case of Sales Force Literature from 1912 to 2019." Journal of Marketing Analytics $8(3): 165-84$.

22.Van Eck, Nees Jan, and Ludo Waltman. 2014. "Visualizing Bibliometric Networks." Pp. 285-320 in Measuring scholarly impact. Springer. 
23.Eck, Nees Jan Van, and Ludo Waltman. 2020. "VOSviewer Manual." (April).

24.Fanelli, Simone, Fiorella Pia Salvatore, Gianluigi De Pascale, and Nicola Faccilongo. 2020. "Insights for the Future of Health System Partnerships in Low-and Middle-Income Countries: A Systematic Literature Review." BMC Health Services Research 20(1):1-13.

25.Gebayew, Chernet, Inkreswari Retno Hardini, Goklas Henry Agus Panjaitan, Novianto Budi Kurniawan, and others. 2018. "A Systematic Literature Review on Digital Transformation." Pp. 26065 in 2018 International Conference on Information Technology Systems and Innovation (ICITSI).

26.Gerdsri, Nathasit, Alisa Kongthon, and Ronald S. Vatananan. 2013. "Mapping the Knowledge Evolution and Professional Network in the Field of Technology Roadmapping: A Bibliometric Analysis." Technology Analysis \& Strategic Management 25(4):403-22.

27.Hallinger, Philip, and Suparak Suriyankietkaew. 2018. "Science Mapping of the Knowledge Base on Sustainable Leadership, 1990--2018." Sustainability 10(12):4846.

28. Hansen, Sune Balle, Rory Padfield, Khadijah Syayuti, Stephanie Evers, Zuriati Zakariah, and Sharifah Mastura. 2015. "Trends in Global Palm Oil Sustainability Research." Journal of Cleaner Production 100:140-49.

29.Hausberg, J. P., K. Liere-Netheler, S. Packmohr, S. Pakura, and K. Vogelsang. 2019. "Research Streams on Digital Transformation from a Holistic Business Perspective: A Systematic Literature Review and Citation Network Analysis." Journal of Business Economics 89(8-9):931-63.

30.Huang, Zhaojing, Hongxiu Chen, and Zuoyan Liu. 2020. "The 100 Top-Cited Systematic Reviews/Meta-Analyses in Central Venous Catheter Research: A PRISMA-Compliant Systematic Literature Review and Bibliometric Analysis." Intensive and Critical Care Nursing 57:102803.

31.Khan, Nohman, Muhammad Imran Qureshi, Ishamuddin Mustapha, Sobia Irum, and Rai Naveed Arshad. 2020. "A Systematic Literature Review Paper on Online Medical Mobile Applications in Malaysia." International Journal of Online and Biomedical Engineering 16(1):63-82.

32.Konys, Agnieszka. 2019. "Towards Sustainable Entrepreneurship Holistic Construct." Sustainability 11(23):6749.

33.Koren, David, and Katarina Rus. 2019. "The Potential of Open Space for Enhancing Urban Seismic Resilience: A Literature Review." Sustainability 11(21):5942.

34.Kovačević, Jasna, and Philip Hallinger. 2019. "Leading School Change and Improvement." Journal of Educational Administration.

35.Li, Feng. 2020. "The Digital Transformation of Business Models in the Creative Industries: A Holistic Framework and Emerging Trends." Technovation 92:102012.

36.Limaj, Everist, and Edward W. N. Bernroider. 2019. "A Systematic Analysis and Synthesis of Case Study Based Agile Scaling Research in the Context of Digital Transformations." Pp. 74-84 in International Conference on Research and Practical Issues of Enterprise Information Systems.

37.Mahmood, Mohamed. 2016. "Enhancing Citizens' Trust and Confidence in Government through Digital Transformation." International Journal of Electronic Government Research (IJEGR) 12(1):99110.

38. Mahraz, Mohamed-iliasse, Loubna Benabbou, Abdelaziz Berrado, and Ecole Mohammadia. 2019. "A Systematic Literature Review of Digital Transformation." 917-31.

39. Mardani, Abbas, Edmundas Kazimieras Zavadskas, Dalia Streimikiene, Ahmad Jusoh, and Masoumeh Khoshnoudi. 2017. "A Comprehensive Review of Data Envelopment Analysis (DEA) Approach in Energy Efficiency." Renewable and Sustainable Energy Reviews 70:1298-1322.

40.Moher, David, Alessandro Liberati, Jennifer Tetzlaff, and Douglas G. Altman. 2009. "Preferred Reporting Items for Systematic Reviews and Meta-Analyses: The PRISMA Statement." PLoS Medicine 6(7):e1000097.

41.Niñerola, Angels, Ramon Ferrer-Rullan, and Antoni Vidal-Suñé. 2020. "Climate Change Mitigation: Application of Management Production Philosophies for Energy Saving in Industrial Processes." Sustainability 12(2):717.

42.Noyons, Ed C. M., Henk F. Moed, and Marc Luwel. 1999. "Combining Mapping and Citation Analysis for Evaluative Bibliometric Purposes: A Bibliometric Study." Journal of the American Society for Information Science 50(2):115-31. 
43.Piccinini, Everlin, Carlos K. Flores, Daniele Vieira, and Lutz M. Kolbe. 2016. "The Future of Personal Urban Mobility--towards Digital Transformation." Wirtschaftsinformatik (MKWI) 55.

44.Pulsiri, Nonthapat, Ronald Vatananan-Thesenvitz, Teera Sirisamutr, and Porntip Wachiradilok. 2019. "Save Lives: A Review of Ambulance Technologies in Pre-Hospital Emergency Medical Services." Pp. 1-10 in 2019 Portland International Conference on Management of Engineering and Technology (PICMET).

45.Qureshi, Muhammad Imran, Nohman Khan, Shazia Qayyum, Subha Malik, Hishan S. Sanil, and Thurasamy Ramayah. 2020. "Classifications of Sustainable Manufacturing Practices in ASEAN Region: A Systematic Review and Bibliometric Analysis of the Past Decade of Research." Sustainability (Switzerland) 12(21):1-19.

46. Ravikumar, Sharina, Ashutosh Agrahari, and Sri Nivas Singh. 2015. "Mapping the Intellectual Structure of Scientometrics: A Co-Word Analysis of the Journal Scientometrics (2005--2010)." Scientometrics 102(1):929-55.

47.Santos-Neto, João Batista Sarmento dos, and Ana Paula Cabral Seixas Costa. 2019. "Enterprise Maturity Models: A Systematic Literature Review." Enterprise Information Systems 13(5):719-69.

48.Satalkina, Liliya, and Gerald Steiner. 2020. "Digital Entrepreneurship and Its Role in Innovation Systems: A Systematic Literature Review as a Basis for Future Research Avenues for Sustainable Transitions." Sustainability 12(7):2764.

49.Savastano, M., C. Amendola, B. Bellini, and F. D’Ascenzo. 2019. "Contextual Impacts on Industrial Processes Brought by the Digital Transformation of Manufacturing: A Systematic Review." Sustainability (Switzerland) 11(3).

50.Schaller, Amaury-Alexandre, and Ronald Vatananan-Thesenvitz. 2019. "Business Model Innovation (BMI) Process: A Systematic Literature Review with Bibliometric Analysis." Pp. 1-12 in 2019 Portland International Conference on Management of Engineering and Technology (PICMET).

51.Schaller, Amaury-Alexandre, Ronald Vatananan-Thesenvitz, Nonthapat Pulsiri, and ArnauldMaximilian Schaller. 2019. "The Rise of Digital Business Models: An Analysis of the Knowledge Base." Pp. 1-13 in 2019 Portland International Conference on Management of Engineering and Technology (PICMET).

52.Sharma, Ravi, and Kripanshi Gupta. 2020. "Life Cycle Modeling for Environmental Management: A Review of Trends and Linkages." Environmental Monitoring and Assessment 192(1):51.

53.Sott, Michele Kremer, Leonardo Bertolin Furstenau, Liane Mahlmann Kipper, Faber D. Giraldo, Jose Ricardo Lopez-Robles, Manuel J. Cobo, Adnan Zahid, Qammer H. Abbasi, and Muhammad Ali Imran. 2020. "Precision Techniques and Agriculture 4.0 Technologies to Promote Sustainability in the Coffee Sector: State of the Art, Challenges and Future Trends." IEEE Access 8:149854-67.

54.Teniwut, W., and C. Hasyim. 2020. "Decision Support System in Supply Chain: A Systematic Literature Review." Uncertain Supply Chain Management 8(1):131-48.

55.Tranfield, David, David Denyer, and Palminder Smart. 2003. "Towards a Methodology for Developing Evidence-Informed Management Knowledge by Means of Systematic Review." British Journal of Management 14(3):207-22.

56.Valverde-Berrocoso, Jesús, Mar\’\ia del Carmen Garrido-Arroyo, Carmen Burgos-Videla, and Mar\’ $\backslash$ ia Belén Morales-Cevallos. 2020. "Trends in Educational Research about E-Learning: A Systematic Literature Review (2009--2018)." Sustainability 12(12):5153.

57.Vatananan-Thesenvitz, Ronald, Amaury-Alexandre Schaller, and Randall Shannon. 2019. "A Bibliometric Review of the Knowledge Base for Innovation in Sustainable Development." Sustainability 11(20): 5783.

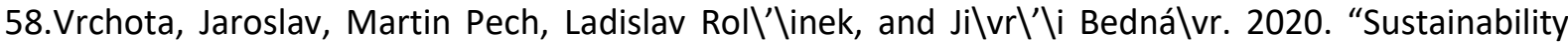
Outcomes of Green Processes in Relation to Industry 4.0 in Manufacturing: Systematic Review." Sustainability 12(15):5968.

59.Wang, Yuxi, Martin McKee, Aleksandra Torbica, and David Stuckler. 2019. "Systematic Literature Review on the Spread of Health-Related Misinformation on Social Media." Social Science \& Medicine 240:112552.

60.Yousefi, Milad, Moslem Yousefi, and Flavio S. Fogliatto. 2020. "Simulation-Based Optimization 
Methods Applied in Hospital Emergency Departments: A Systematic Review." Simulation 0037549720944483.

61.Zou, Xin, Wen Long Yue, and Hai Le Vu. 2018. "Visualization and Analysis of Mapping Knowledge Domain of Road Safety Studies." Accident Analysis \& Prevention 118:131-45.

62.Zupic, Ivan, and Tomaž Čater. 2015. "Bibliometric Methods in Management and Organization." Organizational Research Methods 18(3):429-72. 